[Agr. Biol. Chem., Vol. 33, No. 6, p. 907 914, 1969]

\title{
Exchangeability of Colloidal Calcium in Milk with Soluble Calcium
}

\author{
By Kunio Yamauchi, Yoshiki Yoneda, Yoshikazu Koga \\ and Tomokichi Tsugo
}

Department of Agricultural Chemistry, Faculty of Agriculture, The University of Tokyo, Bunkyo-ku, Tokyo

Received October 26, 1968

\begin{abstract}
Approximately $40 \%$ of the calcium existing in colloidal phase of skimmilk was estimated to be hardly exchanged with the calcium psesent in soluble phase by applying a radioisotopic technique. This type of calcium was designated hard-to-exchange calcium. Hardto-exchange calcium was absent or nearly zero in calcium caseinate dispersion or colloidal phosphate-free milk, but was present in composite calcium caseinate phosphate dispersion. It is suggested that hard-to-exchange calcium is present in a part of colloidal phosphate portion of casein micelles.
\end{abstract}

It has been known that native casein in milk exists as micelles consisting of calcium caseinate and a salt of calcium and phosphate. However, the chemical and the physical structure of this complex has been still uncertain as discussed in an excellent review by Rose." The methods used so far for investigation of the nature of colloidal salt in milk have been rather indirect. In is certainly desirable to explore more direct methods for the investigations on native casein micelles.

In the experiments performed in our laboratory on removal of radioactive strontium from milk, it was found that the ${ }^{90} \mathrm{Sr}$ introduced into milk via cow by injection was less removable with ion exchange resin than the ${ }^{90} \mathrm{Sr}$ added to milk in vitro. ${ }^{21}$ This suggests that the distribution of the ${ }^{90} \mathrm{Sr}$ added to milk might be somewhat different from that of the ${ }^{90} \mathrm{Sr}$ incorporated into milk in vivo

This observation led us to use radioisotopes such as ${ }^{45} \mathrm{Ca}$ and ${ }^{32} \mathrm{P}$ to investigate the nature

1) D. Rose, J. Dairy Sci., 48, 139 (1965).

2) Y. Koga, Y. Ohmomo and T. Tsugo, Abstracts of Papers, 8th Meeting of the Japan Radiation Research Society, Niigata, Sept., 1966, p. 48. of salt equilibrium in milk. Exchanging behavior of the ${ }^{45} \mathrm{Ca}$ added to milk was followed in this report by determining its distribution into soluble and colloidal phases. Merit of this method is that the amount of added ${ }^{46} \mathrm{Ca}$ ions is so small that it does not affect significantly on the salt equilibrium in milk. A similar attempt was made independently by Corradini $e t$ al..$^{31}$ They observed that when ${ }^{45} \mathrm{CaCl}_{2}$ was added to $\mathrm{CaCl}_{2}$ solution of phosphocaseinate obtained from the ultracentrifugation of milk, there was a linear relationship between the proportion of the ${ }^{45} \mathrm{Ca}$ in colloidal phase and the ratio of colloidal calcium to soluble calcium. They also observed that when ${ }^{45} \mathrm{CaCl}_{2}$ was added to skimmilk, the results deviated from the line for phosphocaseinate, presumably because of the presence of soluble citrate and phosphate in milk. Swanson et al..$^{41}$ also pointed out that the ${ }^{45} \mathrm{Ca}$ added to milk did not exchange freely with ionic calcium in their report on secretion of

3) C. Corradini, S. Silva and P. Fontana, XVIIth Itern. Dairy Congr. B: 2, 119 (1966).

4) E. W. Swanson et al., J. Dairy Sci., 39, 1594 (1956). 
${ }^{45} \mathrm{Ca}$ by the mammary glands of cows. However, no adequate explanation has been given in this respect.

The present study provides some additional informations on the equilibrium of calcium in milk, and besides gives the evidence for the occurrence of the calcium in colloidal phase which is hardly exchanged with the calcium present in soluble phase. This type of calcium in colloidal phase is designated "hard-toexchange calcium" in the present investigation.

\section{MATERIALS AND METHODS}

1. Milk and casein. Unpasteurized pooled skimmilk was used for general use. In some experiments milks from individual cows were also used. The individual milks were obtained from Holstein cows at the $\mathrm{Na}$ tional Institute of Animal Industry, Chiba-shi, and were skimmed by centrifugation.

Casein was prepared from pooled skimmilk by usual procedure; twice precipitations at $\mathrm{pH} 4.6$ with hydrochloric acid. The precipitate was exhaustively washed with water and lyophilized. Calcium caseinate dispersion was prepared by adding calcium chloride solution to neutral sodium caseinate solution. The final $\mathrm{pH}$ was adjusted to about 6.7 with diluted sodium hydroxide. The final concentration of protein and calcium were about $2 \%$ and $20 \mathrm{~mm}$, respectively. Calcium caseinate phosphate dispersion was prepared by dissolving $4 \mathrm{~g}$ of acid casein with saturated lime water until $\mathrm{pH}$ became 10.5 and then titrating back with $0.025 \mathrm{M}$ phosphoric acid to $\mathrm{pH} 6.75$. The final volume of the resultant dispersion was approximately $200 \mathrm{ml}$ and its protein concentration was $1.77 \%$.

Colloidal phosphate-free milk was prepared from pooled skimmilk according to the method of Pyne and McGann.5) Chilled skimmilk was acidified to $\mathrm{pH} 4.9$ with concentrated hydrochloric acid and dialyzed against excess of the original skimmilk for 4 days at $4^{\circ} \mathrm{C}$.

2. Separation of soluble phase. Separation of soluble phase from skimmilk or casein dispersions was accomplished by ultrafiltration unless otherwise specified. One $\mathrm{ml}$ of ${ }^{45} \mathrm{CaCl}_{2}$ solution (approximately $10^{6} \mathrm{cpm}$

5) G. T. Pyne and T. C. A. McGann, J. Dairy Research, 27, 9 (1960). per $\mathrm{ml}$; Ca concentration was $1 \sim 2 \times 10^{-3} \mathrm{mg} / \mathrm{ml}$ ) was added to $200 \mathrm{ml}$ of skimmilk or caseinate dispersions containing $1 \mathrm{ml}$ of chloroform as a preservative and mixed immediately. The mixture was ultrafiltered at proper intervals, usually, (1) immediately after addition of ${ }^{45} \mathrm{CaCl}_{2},(2)$ after standing at room temperature for $24 \mathrm{hr}$, and (3) for $48 \mathrm{hr}$. Each time two $25 \mathrm{ml}$-aliquots of the sample were ultrafiltered under reduced pressure for one hr by using two collodion sacs $(2 \times 10 \mathrm{~cm})$ made from $5 \%$ collodion solution in ethanol-ether $(1: 3 \mathrm{v} / \mathrm{v})$ mixture (Koso Chemical Co., Ltd.) The filtrates from the sacs were combined and analyzed. About $4 \mathrm{ml}$ of the filtrate was obtained from $50 \mathrm{ml}$ of skimmilk during one hr.

Rennin clotting method and equilibrium dialysis method were also applied to prepare soluble phase in some experiments. One tenth $\mathrm{ml}$ of rennin solution containing $10 \mathrm{mg}$ of purified rennin ${ }^{6}$ per $\mathrm{ml}$ was added at proper intervals to a $5 \mathrm{ml}$ aliquot of the skimmilk to which ${ }^{45} \mathrm{Ca}$ had been previously added. Prior to the addition of rennin, skimmilk was preincubated for a few minutes in a water bath kept at $30^{\circ} \mathrm{C}$. Coagulation took place within $2 \mathrm{~min}$ under this condition. Whey was immediately separated by centrifugation ( $2000 \mathrm{rpm}, 5 \mathrm{~min}$ ). Equilibrium dialysis was carried out in the same way as described by Davies and White." Eight $\mathrm{ml}$ of water was introduced into a cellophane tube (Visking Co., d. $1.4 \mathrm{~cm}$ ) and dialyzed against $200 \mathrm{ml}$ of the skimmilk to which $1 \mathrm{ml}$ of ${ }^{45} \mathrm{CaCl}_{2}$ solution had been added. After dialysis at $20^{\circ} \mathrm{C}$ for $48 \mathrm{hr}$ with occasional stirring, the dialyzate was taken out and analyzed. In the case of rennin clotting or equilibrium dialysis method, a small amount of chloroform was also added as a preservative.

3. Analysis. Calcium content in the sample was determined by a back titration method ${ }^{8 /}$ after addition of excess EDTA solution with standard calcium chloride solution. Phosphorus was determined by the modification of Allen's method' and nitrogen by micro Kjeldahl method.

Radioactivity in the sample was determined either by a standard method or by a rapid method. In the

6) U. Yoshino, N. Nakatani, Y. Tokoro and K. Yamauchi, Nippon Nogeikagaku Kaishi, 40, 52 (1966).

7) D. T. Davies and J. C. D. White, J. Dairy Research, 27, 171 (1960).

8) T. H. Kamal, J.Agr. Food Chem., 8, 156 (1960).

9) M. Nakamura, Nippon Nogeikagaku Kaishi, 24, 1 (1950). 
standard method one $\mathrm{ml}$ of the sample was ashed at $550^{\circ} \mathrm{C}$ with calcium chloride (equivalent to $10 \mathrm{mg} \mathrm{Ca}$ ) added as a carrier. A few drops of fuming nitric acid were added to the ash, dried up by heating and then the ash was dissolved with proper amount of water. The content was filtered and the filtrate was neutralized with concentrated ammonium hydroxide after adding phenolphthalein as the indicator. Then the same volune of the saturated ammonium carbonate solution was added to the solution. The solution was left overnight and the precipitated calcium carbonate was collected on filter paper and washed with water. After drying up, the radioactivity was determined by a Model IDC-IC radiation counter (Nihon Musen Co., Ltd.)

In the rapid method, $0.1 \mathrm{ml}$ of the sample was spotted on a piece of filter paper (Toyo Filter Paper No. $5 B, d .2 .5 \mathrm{~cm}$ ) put in a dish. After the sample was dried up, the radioactivity was determined directly. Because of convenience and rapidity, the latter method was used in most experiments unless otherwise stated. The relationship between the amount of sample applied and the activity determined by the rapid method was checked on the skimmilk and the rennin whey to which appropriate amount of ${ }^{45} \mathrm{CaCl}_{2}$ solution was added. As seen in Fig. 1, a linear relationship was

(a) Skimmilk

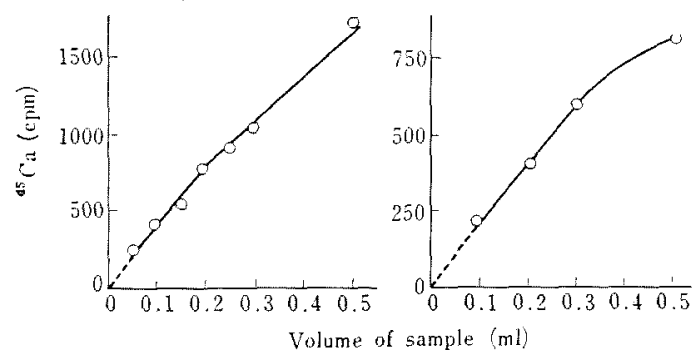

FIG. 1. Relationship between Sample Size and ${ }^{45} \mathrm{Ca}$ Activity Determined by Rapid Method.

(a) and (b) are independent experiments and therefore can not be compared with each other.

obtained within the range of $0.1 \sim 0.2 \mathrm{ml}$ and $0.1 \sim$ $0.3 \mathrm{ml}$ for skimmilk and for rennin whey, respectively. Above these ranges the ratio of $\mathrm{cpm}$ to sample size decreased probably because of the sheltering effect of the large amount of milk solids on $\beta$-counting. Next experiment was conducted to see the effect of media on ${ }^{45} \mathrm{Ca}$ activity determination by the rapid method. Aliquots of $2 \mathrm{ml}$ of skimmilk, rennin whey, ultra-

filtrate of skimmilk or water were taken in test tubes and varying amount of diluted ${ }^{45} \mathrm{CaCl}_{2}$ solution was added to each tube. The volume of each mixture was made up to $2.5 \mathrm{ml}$ with water. Two tenth $\mathrm{ml}$ from each mixture was spotted on filter paper and the activity was determined. As shown in Fig. 2, a

(a) Skimmilk, rennin whey, and water (b) Skimmilk, uetrafiltrate, and water

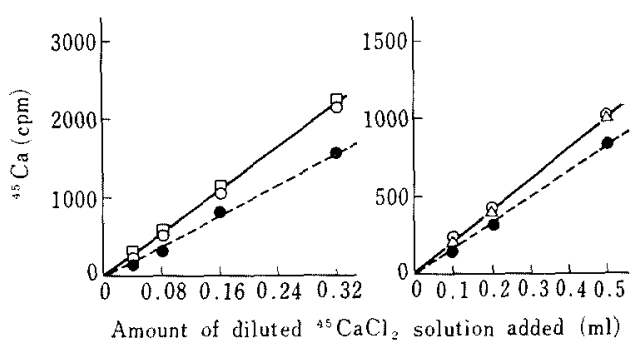

FIG. 2. Effect of Media on ${ }^{45} \mathrm{Ca}$ Activity Determined by Rapid Method.

(a) and (b) are independents experiments and therefore can not be compared with each other.

$\begin{array}{ll}0-0 & \text { Skimmilk } \\ \square-\square & \text { Rennin whey } \\ \triangle-\triangle & \text { Ultrafiltrate } \\ --\square & \text { Water }\end{array}$

good agreement was obtained for calibration curves of ${ }^{45} \mathrm{Ca}$ in skimmilk, rennin whey and ultrafiltrate within the range of experimental error. It is therefore concluded that the rapid method can be used for direct comparison of the radioactivity without further correction, as far as skimmilk, rennin whey and ultrafiltrate are compared. However, the activity in water gave considerably lower value than in milk. This discrepancy seemed to be due to the difference of milk (or its fractions) and water in their behaviors to diffuse into filter paper, but the investigation on this point was not further performed.

The rapid and the standard methods were compared in one of the calcium exchange experiments described later and it was found that both methods gave an almost identical value for proportion of ${ }^{45} \mathrm{Ca}$ of soluble phase in milk (see footnote in Table I).

4. Calculation. If it is assumed that the exchange between ionic calcium (added ${ }^{45} \mathrm{Ca}$ was of this form) and non-ionic soluble calcium reaches to an equilibrium state within a very short time compared with the exchange between the calcium in soluble phase and that in colloidal phase, the proportion of the exchang- 
ed calcium $\left(\% \mathrm{Ca}_{\mathrm{ex}}\right)$ in colloidal phase to total colloidal calcium can be calculated by the following formula,

$$
\% \mathrm{Ca}_{\mathrm{ex}}=\frac{100-{ }^{45} \mathrm{Ca}_{\text {sol }}}{{ }^{45} \mathrm{Ca}_{\text {sol }}} \times \frac{\mathrm{Ca}_{\text {sol }}}{100-\mathrm{Ca}_{\text {sol }}} \times 100
$$

where ${ }^{45} \mathrm{Ca}_{\text {sol }}$ is the percentage of ${ }^{45} \mathrm{Ca}$ activity remaining in soluble phase per total activity added; $\mathrm{Ca}_{\text {sol }}$ is the percentage of calcium content in soluble phase per total calcium content in original skimmilk. This formula is essentially the same to the formula derived by Neuman et al. or others for the radioisotopic study of bone minerals. ${ }^{10,111}$

\section{RESULTS}

\section{Exchange of calcium in milk}

Exchange of calcium between soluble and colloidal phase in milk was determined on four different lots of pooled skimmilk by the ultrafiltration method. The result indicated in Table I shows that the exchange was relatively rapid; approximately half of colloidal calcium was exchanged within one hr. How- ever, the exchange proceeded further until an equilibrium state was attained. Generally, the maximum of $\mathrm{Ca}_{\mathrm{ex}}$ was obtained after one or two days. It might be questionable to conclude that the equilibrium state had been attained at this stage in the strict sense, but the present study could not evaluate a slow exchange process beyond a few days, if it actually exists, because of (a) relatively large experimental error, and (b) difficulty to continue the exchange experiment for longer time without possible deterioration of milk itself. Approximate proportion of hard-to-exchange calcium estimated from $100-\% \mathrm{Ca}_{\text {ex }}$ at $48 \sim$ $49 \mathrm{hr}$ was $33 \sim 38 \%$ (average 36\%) for sample $2 \sim 4$ and $22 \%$ for sample 1 . Smaller proportion of the hard-to-exchange calcium in sample 1 may be related to the lower $\mathrm{pH}$ value of this sample compared with usual milk.

Similar experiments were performed on six different individual milk samples. Results are shown in Table II. Hard-to-exchange calcium estimated from 100-\% $\mathrm{Ca}_{\mathrm{ex}}$ at $48 \sim$

Table I. EXchange of Ca IN Pooled SKimmilk

\begin{tabular}{|c|c|c|c|c|c|c|c|c|}
\hline \multirow[t]{2}{*}{$\begin{array}{l}\text { Milk } \\
\text { No. }\end{array}$} & \multirow[t]{2}{*}{$\begin{array}{c}\text { Ca concn. in } \\
\text { skimmilk (mg/ml) }\end{array}$} & \multicolumn{2}{|c|}{$\begin{array}{c}\text { Time } \\
(\mathrm{hr})\end{array}$} & \multirow{2}{*}{$\begin{array}{c}\mathrm{pH} \\
6.58\end{array}$} & \multirow{2}{*}{$\begin{array}{c}\mathrm{Co}_{\text {sol }} \\
(\%) \\
34.1\end{array}$} & \multirow{2}{*}{$\begin{array}{c}{ }^{45} \mathrm{Ca}_{\text {Sol }} \\
(\%) \\
48.3\end{array}$} & \multirow{2}{*}{$\begin{array}{l}\text { 96 } \mathrm{Ca}_{\mathrm{ex}} \\
55.4\end{array}$} & \multirow{2}{*}{$\begin{array}{c}100-\% \mathrm{Ca}_{\mathrm{ex}} \\
44.6\end{array}$} \\
\hline & & (1) & $0 \sim 1$ & & & & & \\
\hline \multirow[t]{3}{*}{1} & 1.026 & (2) & $24 \sim 25$ & 6.52 & 31.1 & 36.4 & 78.9 & 21.1 \\
\hline & & (3) & $48 \sim 49$ & 6.50 & 32.1 & 37.7 & 78.2 & 21.8 \\
\hline & & (1) & $0 \sim 1$ & 6.70 & 31.3 & $\begin{array}{c}47.5 \\
(47.4) *\end{array}$ & 50.3 & 49.7 \\
\hline \multirow[t]{3}{*}{2} & 1.037 & (2) & $24 \sim 25$ & 6.70 & 29.8 & $\begin{array}{c}39.2 \\
(38.1)^{*}\end{array}$ & 65.8 & 34.2 \\
\hline & & (3) & $48 \sim 49$ & 6.63 & 29.8 & $\begin{array}{c}39.7 \\
(40.1) *\end{array}$ & 64.5 & 35.5 \\
\hline & & (1) & $0 \sim 1$ & 6.82 & 33.7 & 53.6 & 44.0 & 56.0 \\
\hline \multirow{4}{*}{3} & 1054 & (2) & $24 \sim 25$ & 6.82 & 32.7 & 44.4 & 60.8 & 39.2 \\
\hline & 1.004 & (3) & $48 \sim 49$ & 6.82 & 30.1 & 39.1 & 67.1 & 32.9 \\
\hline & & (4) & $72 \sim 73$ & 6.80 & 30.5 & 39.4 & 67.5 & 32.5 \\
\hline & & (1) & $0 \sim 1$ & 6.72 & 30.3 & 47.1 & 48.8 & 51.2 \\
\hline \multirow[t]{2}{*}{4} & 1.166 & (2) & $24 \sim 25$ & 6.72 & 29.8 & 41.5 & 59.8 & 40.2 \\
\hline & & (3) & $48 \sim 49$ & 6.70 & 29.8 & 40.8 & 61.6 & 38.4 \\
\hline
\end{tabular}

Temperature during exchange experiment was $17 \sim 21^{\circ} \mathrm{C}$.

* Figures in brackets were obtained by the standard method. Others were by the rapid method.

10) W. F. Neuman et al., J. Biol. Chem., 179, 335 (1949).

11) M. Falkenheim, E. E. Underwood and H. C. Hodge, ibid., 188, 805 (1951). 
Table II. Exchange of Ca In Individual Skimmilk

\begin{tabular}{|c|c|c|c|c|c|c|c|c|}
\hline \multirow[t]{2}{*}{$\begin{array}{l}\text { Milk } \\
\text { No. }\end{array}$} & \multirow[t]{2}{*}{$\begin{array}{c}\text { Ca concn. in } \\
\text { skimmilk (mg/ml) }\end{array}$} & \multicolumn{2}{|c|}{$\begin{array}{l}\text { Time } \\
(\mathrm{hr})\end{array}$} & \multirow{2}{*}{$\begin{array}{l}\mathrm{pH} \\
6.70\end{array}$} & \multirow{2}{*}{$\begin{array}{c}\mathrm{Ca}_{\text {sol }} \\
(\%) \\
37.3\end{array}$} & \multirow{2}{*}{$\begin{array}{l}{ }^{45} \mathrm{Ca}_{\text {sol }} \\
(\%) \\
59.0\end{array}$} & \multirow{2}{*}{$\begin{array}{c}\% \mathrm{Ca}_{\mathrm{ex}} \\
42.4\end{array}$} & \multirow{2}{*}{$\begin{array}{c}100-9 \mathrm{Ca}_{\mathrm{ex}} \\
57.6\end{array}$} \\
\hline & & (1) & $0 \sim \mathrm{I}$ & & & & & \\
\hline \multirow[t]{3}{*}{1} & 0.893 & (2) & $24 \sim 25$ & 6.71 & 31.8 & 42.8 & 62.3 & 37.7 \\
\hline & & (3) & $48 \sim 49$ & 6.78 & 32.5 & 40.9 & 69.6 & 30.4 \\
\hline & & (1) & $0 \sim 1$ & 6.61 & 27.9 & 45.6 & 46.1 & 53.9 \\
\hline \multirow[t]{3}{*}{2} & 1.094 & (2) & $24 \sim 25$ & 6.60 & 26.3 & 39.4 & 54.9 & 45.1 \\
\hline & & (3) & $48 \sim 49$ & 6.69 & 24.1 & 35.1 & 58.7 & 41.3 \\
\hline & & (1) & $0 \sim 1$ & 6.64 & 35.4 & 54.7 & 45.4 & 54.6 \\
\hline \multirow[t]{3}{*}{3} & 0.982 & (2) & $24 \sim 25$ & 6.64 & 32.8 & 46.7 & 55.7 & 44.3 \\
\hline & & (3) & $48 \sim 49$ & 6.71 & 33.1 & 45.2 & 60.0 & 40.0 \\
\hline & & (1) & $0 \sim 1$ & 6.59 & 28.3 & 49.7 & 40.0 & 60.0 \\
\hline \multirow[t]{3}{*}{4} & 1.223 & (2) & $24 \sim 25$ & 6.60 & 26.6 & 39.8 & 54.8 & 45.2 \\
\hline & & (3) & $48 \sim 49$ & 6.66 & 26.9 & 40.8 & 53.4 & 46.6 \\
\hline & & (1) & $0 \sim 1$ & 6.79 & 25.0 & 43.1 & 44.0 & 56.0 \\
\hline \multirow[t]{3}{*}{5} & 1.062 & (2) & $24 \sim 25$ & 6.78 & 23.9 & 35.2 & 57.9 & 42.1 \\
\hline & & (3) & $48 \sim 49$ & 6.84 & 24.1 & 32.9 & 64.8 & 35.2 \\
\hline & & (1) & $0 \sim 1$ & 6.68 & 32.6 & 54.0 & 41.2 & 58.8 \\
\hline \multirow[t]{3}{*}{6} & 0.975 & (2) & $24 \sim 25$ & 6.67 & 30.5 & 42.0 & 60.6 & 39.4 \\
\hline & & (3) & $48 \sim 49$ & 6.70 & 29.5 & 40.8 & 60.7 & 39.3 \\
\hline & & (1) & $0 \sim 1$ & & & & 43.2 & 56.8 \\
\hline \multirow[t]{2}{*}{ Average } & & (2) & $24 \sim 25$ & & & & 57.7 & 42.3 \\
\hline & & (3) & $48 \sim 49$ & & & & 61.2 & 38.8 \\
\hline
\end{tabular}

Temperature during exchange experiment was $16 \sim 18^{\circ} \mathrm{C}$.

Sample No. 6 is $70 \%$ alcohol positive. Others are negative.

TABle III. EXchange OF Ca IN SKImmilk Determined by Rennin Clotting AND EqUILIBRIUM DIALYSIS METhods

\begin{tabular}{|c|c|c|c|c|c|c|c|c|}
\hline $\begin{array}{l}\text { Milk } \\
\text { No. }\end{array}$ & Method & $\begin{array}{c}\text { Ca concn. } \\
\text { in skimmilk } \\
(\mathrm{mg} / \mathrm{ml})\end{array}$ & $\begin{array}{l}\text { Time } \\
(\mathrm{hr})\end{array}$ & $\mathrm{pH}$ & $\begin{array}{r}\mathrm{Ca}_{\text {sol }} \\
(\%)\end{array}$ & $\begin{array}{c}{ }^{45} \mathrm{Ca}_{301} \\
(\%)\end{array}$ & $9 \mathrm{Ca}_{\mathrm{ex}}$ & $100-\% \mathrm{Ca}_{\mathrm{ex}}$ \\
\hline \multirow{4}{*}{$4 *$} & \multirow{4}{*}{ Rennin clotting } & \multirow{4}{*}{1.166} & 0.05 & 6.72 & 31.8 & 61.8 & 28.8 & 71.2 \\
\hline & & & 1 & - & 32.0 & 52.4 & 42.7 & 57.3 \\
\hline & & & 4 & - & 31.8 & 50.7 & 45.3 & 54.7 \\
\hline & & & 49 & 6.70 & 31.8 & 44.6 & 57.9 & 42.1 \\
\hline 5 & Equilibrium dialysis & 1.116 & 48 & 6.72 & 31.2 & 39.2 & 70.3 & 29.7 \\
\hline
\end{tabular}

* This milk was the same to the No. 4 milk in Table I.

$49 \mathrm{hr}$ varied from about 30 to $47 \%$ depending on sample, and gave an avarage $39 \%$. Sample 6 coagulated upon addition of equal volume of $70 \%$ alcohol but the acidity of this milk was rather low $(0.97 \%)$. This type of alcohol positive milk has been sometimes found in Japan. ${ }^{121}$ No particular characteristic of calcium exchange appeared to be indicative of

12) M. Maeno, Jap. J. Zootech. Sci., 28, 197 (1957). this abnormal sample.

The occurrence of hard-to-exchange calcium was also confirmed by the rennin clotting and the equilibrium dialysis methods (Table III). Pooled skimmilk was used in these experiments. The milk used for the rennin clotting method was the same to one of the milk samples used for ultrafiltration method (No. 4 in Table 1). The rennin clotting method gave a slightly higher percentage of $\mathrm{Ca}_{\text {sol }}$ than 
the ultrafiltration method. It might be because the rennin whey contained nonfiltrable whey constituents (e.g. $\beta$-lactoglobulin) capable to bind calcium to some extent. If one assumes that the exchange of calcium takes place completely in these constituents, a slightly lower value of $\% \mathrm{Ca}_{\mathrm{ex}}$ obtained by the rennin clotting method could be explained.

In order to make sure that the indication for the presence of hard-to-exchange calcium is not attributed to artifacts of the experimental procedures, an experiment was conducted on the skimmilk, whose $\% \mathrm{Ca}_{\mathrm{ex}}$ was supposed to be 100. After addition of ${ }^{45} \mathrm{CaCl}_{2}$ to skimmilk it was acidified to $\mathrm{pH} 2.5$ with concentrated hydrochloric acid, and then back titrated to $\mathrm{pH} 6.80$ with concentrated sodium hydroxide solution. Over-all dilution due to this treatment was about 1.08. After neutralization the sample was allowed to stand for one $\mathrm{hr}$ and then ultrafiltered. Complete exchange of calcium was attained; i.e. ${ }^{45} \mathrm{Ca}$

\section{Table IV. Exchange of Ca IN Skimmilk WHEN ACIDIFIED AFTER ADDITION OF ${ }^{45} \mathrm{Ca}$ AND THEN NEUTRALIZED

$\begin{array}{ccccc}\begin{array}{c}\mathrm{Ca} \text { concn. } \\ \text { in skimmilk } \\ (\mathrm{mg} / \mathrm{ml})\end{array} & \mathrm{pH} & \begin{array}{c}\mathrm{Ca}_{\text {sol }} \\ (\%)\end{array} & \begin{array}{c}{ }^{45} \mathrm{Ca}_{\text {sol }} \\ (\%)\end{array} & \% \mathrm{Ca}_{3 \mathrm{x}} \\ 1.017 & 6.75 & 32.8 & 32.6 & 100.9\end{array}$

Milk was allowed to stand for one hr at $21^{\circ} \mathrm{C}$ after neutralization, and then ultrafiltered. was distributed evenly into soluble and colloidal phases, as indicated in Table IV

\section{Exchange of calcium in colloidal phosphate-free milk}

$\mathrm{Ca}_{\mathrm{ex}}$ in colloidal phosphate-free milk was estimated by the ultrafiltration method. The radioactivity was determined by the rapid method. $\mathrm{Ca}_{\text {ex }}$ in this system approached to nearly $100 \%$ after $48 \sim 49 \mathrm{hr}$, as indicated in Table V. However, the speed of the exchange was relatively slow compared with that in calcium caseinate dispersion (see next).

Table V. Exchange of Ca IN Colloidal PHOSPHATE-FREE MILK

$\begin{array}{ccccccc}\begin{array}{c}\text { Exp. } \\ \text { No. }\end{array} & \begin{array}{l}\text { Time } \\ (\mathrm{hr})\end{array} & \mathrm{pH} & \begin{array}{c}\mathrm{Ca}_{\text {sol }} \\ (\%)\end{array} & \begin{array}{c}{ }^{45} \mathrm{Ca}_{\text {sol }} \\ (\%)\end{array} & \% \mathrm{Ca}_{3 \mathrm{x}} \\ & (1) & 0 \sim 1 & 6.69 & 60.1 & 67.0 & 74.2 \\ 1 & (2) & 24 \sim 25 & 6.69 & 59.6 & 63.8 & 83.7 \\ & (3) & 48 \sim 49 & 6.69 & 55.6 & 56.7 & 95.6 \\ & (1) & 0 \sim 1 & 6.79 & 65.9 & 68.5 & 88.9 \\ 2 & (2) & 24 \sim 25 & 6.75 & 60.0 & 63.1 & 87.8 \\ & (3) & 48 \sim 49 & 6.74 & 58.2 & 58.9 & 97.2\end{array}$

Concn. $(\mathrm{mg} / \mathrm{ml})$ of $\mathrm{Ca}$ and inorg. $\mathrm{P}(\mathrm{IP})$ in

\begin{tabular}{|c|c|c|c|c|}
\hline \multirow[t]{2}{*}{$\begin{array}{l}\text { Exp. } \\
\text { No. }\end{array}$} & \multicolumn{2}{|c|}{$\begin{array}{l}\text { original } \\
\text { skimmilk }\end{array}$} & \multicolumn{2}{|c|}{$\begin{array}{l}\text { colloidal phosphate } \\
\text { free skimmilk }\end{array}$} \\
\hline & $\mathrm{Ca}$ & IP & $\mathrm{Ca}$ & IP \\
\hline 1 & 1.092 & 0.636 & 0.520 & 0.381 \\
\hline 2 & 1.097 & 0.614 & 0.566 & 0.363 \\
\hline
\end{tabular}

Temperature during exchange experiment was $14 \sim 19^{\circ} \mathrm{C}$.

Table VI. Exchange of Ca in Calcium Caseinate Dispersion

\begin{tabular}{|c|c|c|c|c|c|c|c|c|}
\hline \multirow[t]{2}{*}{$\begin{array}{l}\text { Exp. } \\
\text { No* }\end{array}$} & \multicolumn{3}{|c|}{$\begin{array}{c}\text { Concn. in original dispersion } \\
(\mathrm{mg} / \mathrm{ml})\end{array}$} & \multirow[t]{2}{*}{$\begin{array}{l}\text { Time } \\
\text { (hr) }\end{array}$} & \multirow[t]{2}{*}{$\mathrm{pH}$} & \multirow[t]{2}{*}{$\begin{array}{r}\mathrm{Ca}_{\text {sol }} \\
(\%)\end{array}$} & \multirow[t]{2}{*}{$\begin{array}{l}{ }^{45} \mathrm{Ca}_{\mathrm{sol}} \\
(\%)\end{array}$} & \multirow[t]{2}{*}{$\% \mathrm{Ca}_{\mathrm{ex}}$} \\
\hline & $\mathrm{Ca}$ & Protein & Lactose & & & & & \\
\hline & & & & (1) $0 \sim 1$ & 6.75 & 61.9 & 62.0 & 99.5 \\
\hline \multirow[t]{2}{*}{1} & 0.801 & 20.08 & 0 & (2) $24 \sim 25$ & 6.72 & 60.5 & 60.0 & 102.1 \\
\hline & & & & (3) $48 \sim 49$ & 6.72 & 60.8 & 61.0 & 99.2 \\
\hline \multirow[t]{2}{*}{2} & 0.822 & 19.20 & 40 & (1) $0 \sim 1$ & 6.70 & 63.2 & 64.4 & 94.9 \\
\hline & & & & (2) $24 \sim 25$ & 6.70 & 64.5 & 64.0 & 102.2 \\
\hline 3 & 0.825 & 19.13 & 0 & - & 6.72 & 62.7 & 62.6 & 100.3 \\
\hline
\end{tabular}


Table VII. Exchange of Ca in Composite Calcium Caseinate Phosphate Dispersion

\begin{tabular}{|c|c|c|c|c|c|c|c|c|}
\hline \multicolumn{3}{|c|}{$\begin{array}{c}\text { Concn. in original dispersion } \\
(\mathrm{mg} / \mathrm{ml})\end{array}$} & \multirow{2}{*}{\multicolumn{2}{|c|}{$\begin{array}{l}\text { Time } \\
(\mathrm{hr})\end{array}$}} & \multirow[t]{2}{*}{$\mathrm{pH}$} & \multirow[t]{2}{*}{$\begin{array}{c}\mathrm{Ca}_{\mathrm{sol}} \\
(\%)\end{array}$} & \multirow[t]{2}{*}{$\begin{array}{l}{ }^{45} \mathrm{Ca}_{\text {sol }} \\
(\%)\end{array}$} & \multirow[t]{2}{*}{$\% \mathrm{Ca}_{3 \mathrm{x}}$} \\
\hline $\mathrm{Ca}$ & Protein & IP & & & & & & \\
\hline \multirow[t]{2}{*}{0.618} & 17.65 & 0.208 & & $0 \sim 1$ & 6.76 & 19.3 & 27.6 & 62.7 \\
\hline & & & (3) & $48 \sim 49$ & 6.74 & 19.3 & 26.0 & 68.1 \\
\hline
\end{tabular}

Temperature during exchange experiment was $13 \sim 17^{\circ} \mathrm{C}$.

\section{Exchange of calcium in composite caseinate dispersions}

Radioactivity in composite caseinate dispersions and their ultrafiltrates was determined by the standard method. The result on exchange of the calcium in calcium caseinate dispersion is shown in Table VI. Hard-toexchange calcium was absent in this system, and besides the speed of the exchange was quite rapid. Complete exchange has been attained within the period of first ultrafiltration (Table VI, Exp. 1). Exp. 2 was performed to see the effect of lactose. The presence of lactose in such concentration as in milk did not affect the exchangeability of calcium. Exp. 3 was performed on the calcium caseinate dispersion made by adding isotope-containing calcium chloride solution into sodium caseinate solution with the same purpose as in the case of the experiment of Table IV Complete exchange of calcium was attained as well.

Differing from the result on calcium caseinate dispersion, there was an indication for the presence of hard-to-exchange calcium in calcium caseinate phosphate dispersion, as shown in Table VII. The amount of $\mathrm{Ca}_{\mathrm{ex}}$ after $48 \sim 49 \mathrm{hr}$ was comparable to that of certain milk samples but the speed of the exchange appeared to be faster than that in milk.

\section{DISCUSSION}

With regard to the speed and the extent of calcium exchange in milk, at least two factors should be taken into account. One is the state of calcium in colloidal phase and the other is the form of calcium in soluble phase.
As the $\% \mathrm{Ca}_{\mathrm{ex}}$ is almost $100 \%$ in colloidal phosphate-free milk and in calcium caseinate dispersion, the occurrence of hard-to-exchange calcium in milk is assumed to be derived from the incorporation of phosphate into colloidal phase. This assumption is also consistent with the observation that a considerable amount of colloidal calcium was hardly exchanged in composite calcium caseinate phosphate dispersion. However, it is premature to discuss about the form of colloidal calcium in milk from a quantitative view, as the exchanging behavior of calcium in salt itself has not been investigated. It is reported that the calcium in ashed bone or in hydroxyapatite does exchange with ionic calcium to some extent. ${ }^{10,11,13)}$ Probably the exchange of calcium in colloidal phase of milk takes place not only in the calcium bound directly to casein or some non-ultrafiltrable whey constituents, but also in a part of the calcium present as colloidal phosphate.

Another aspect to be considered is that the calcium in soluble phase of milk exists as both ionic and non-ionic forms. ${ }^{14}$ It is uncertain whether the exchange takes place solely through ionic calcium. Non-ionic ultrafiltrable calcium may also participate to the exchange reaction directly. However, the relatively slow exchange in colloidal phosphate-free milk compared with the exchange in calcium caseinate dispersion seems to suggest that the exchange through the non-ionic calcium may

13) C. Y. C. Pak and F. C. Bartter, Biochim. Biophys. Acta, 141, 401 (1967).

14) R. Jenness and S. Patton, "Principles of Dairy Chemistry," John Wiley and Sons Inc., New York, N. Y., 1959 , p. 169. 
be slow if it occurrs. The rapid exchange in calcium caseinate dispersion appears to be due to a sole and predominant existence of ionic calcium in the soluble phase of this system. It may be also suggested from the rapidity of the exchange in calcium caseinate dispersion that the aggregate formation of casein into micellar form in itself dose not necessarily retard the exchanging speed. However, in order to find the relation between the speed of exchange and the state of casein micelles, it is necessary to perform exact kinetic studies.
Quick separation of soluble phase is essential for this purpose. The method used in hydrogen exchange studies of protein, ${ }^{15)}$ for example, might be applicable.

Acknowledgements. The authors are indebted to Mr. T. Morichi of the National Institute of Animal Industry for his kind arrangement for collecting individual milk samples.

15) S. W. Englander and D. Crowe, Anal. Biochem., 12,579 (1965). 